\title{
Diagnosis of Boron Deficiency in Green Dwarf Coconut Palm
}

\author{
Leandro Glaydson da Rocha Pinho', Pedro Henrique Monnerat'2, André Assis Pires1, \\ Marta Simone Mendonça Freitas ${ }^{2}$, Claudio Roberto Marciano \\ ${ }^{1}$ Instituto Federal do Espírito Santo, Campus Itapina, Colatina, Brazil \\ ${ }^{2}$ Universidade Estadual do Norte Fluminense, Campos dos Goytacazes, Brazil \\ Email: leandrogrpinho@hotmail.com, monnerat@uenf.br, andre.pires@ifes.edu.br, msimone@uenf.br, \\ marciano@uenf.br
}

Received 10 January 2015; accepted 24 January 2015; published 27 January 2015

Copyright (C) 2015 by authors and Scientific Research Publishing Inc.

This work is licensed under the Creative Commons Attribution International License (CC BY).

http://creativecommons.org/licenses/by/4.0/

(c) (i) 0pen Access

\begin{abstract}
The diagnosis of boron deficiency in coconut palms has been hampered by lack of information about its distribution in the plant. Two experiments were conducted, one in a greenhouse to induce boron deficiency in dwarf green coconut palms, and other in the field, in which the plants received doses of boric acid, $\mathrm{B}(\mathrm{OH})_{3}$. The objective was to verify symptoms of boron deficiency and boron content variation in canopy, leaves and folioles (or leaflets). Boron deficient plants led leaves and folioles to become deformed. The deficient and sufficient contents of boron varied significantly in the canopy, but did not vary in leaves. The boron content increased significantly from bottom to the apex of the folioles in both treatments. To survey the level of boron in the coconut palm, the ideal is, using samples taken from the youngest leaf, to calculate the relation between the boron content in the apex of the foliole and the content in the center or in the folioles bottom, with minimum values 2.2 or 2.7 , respectively.
\end{abstract}

\section{Keywords}

Symptoms, Leaf Analysis, Deficiency Induction, Boric Acid, Samples, Cocos nucifera

\section{Introduction}

In the last years, some progress was achieved in understanding boron's (B) dynamics in soil and plants, but questions remain about its behavior in soils, its role in plant metabolism and, mainly, about the content in leaves which are indicators of deficiency.

In fruit trees boron deficiency mischaracterizes the fruit at the chemical, nutritional and morphological levels, 
hampering the fruit commercialization [1] [2]. There are several cultivated species with B deficiency, which, in turn, often occurs in sandy soil due to lixiviation. However, coconut palm grown in sandy soil with $710 \mathrm{~g} \cdot \mathrm{kg}^{-1} \mathrm{of}$ sand and $31 \mathrm{~g} \cdot \mathrm{kg}^{-1}$ of organic matter in the layer of $0-0.4 \mathrm{~m}$, plants absorbed $\mathrm{B}$, with no evidence of lixiviation after supplying the soil with $60 \mathrm{~g}$ of boric acid per plant [3].

In many parts of the world there are reports of boron deficiency in palms [4] [7]. The diagnosis of boron deficiency in coconut palms (Cocos nucifera L.) has been hampered by lack of information about the distribution of $\mathrm{B}$ on the plant leaves.

Symptoms of B deficiency are associated with two important roles of boron in plant physiology: its participation in the growth of the cell wall and the plasma membrane [8]; and due to its limited mobility, or immobility, in many cultivated species [9]. In the coconut palms, B deficiency decreases the photosynthetic capacity, since it reduces the electron transportation of photosystem II (-12.5\%), photosynthesis $(35.7 \%)$, sweating $(-32.2 \%)$ and stomatal conductance (-45.6\%) [10]. Symptoms of B deficiency become visible as soon as the leaf emerges, which occurs two or more months after the occurrence of the deficiency. The coconut palm grows one leaf per month [11] and a transitory boron deficiency can affect leaf development just days before its full growth [7].

[12] found in the indicator leaf (leaf 9 or 14, listed from the youngest to oldest leaf), levels above the critical level, $8 \mathrm{mg} \cdot \mathrm{kg}^{-1}$ [13], and the plants presented symptoms of B deficiency. Symptoms of boron deficiency in coconut always appear on young leaves [7]-[12] and, in this case, the analysis of the leaf tissue of more developed leaves cannot be a good indicator of the current status of B in the plant.

In these plants boron deficiency can be intensified over time, presenting as initial symptoms leaf area reduction, followed by, days or months later, an increase in leaf senescence, and ultimately, necrosis of the apical meristem. Boron deficiency can also be chronic, affecting many leaves throughout the development. Symptoms can be confounded with attack of plagues and diseases [14], deficiency of zinc, copper, and manganese, toxicity caused by herbicides and others [6]-[15].

Boron deficiency also compromises the coconut palm's radicular system, decreasing the percentage of fine roots, increasing the percentage of thick roots, causing over sprouting, necrosis, darkening and thickening of roots [8]. With the compromising of the radicular system, the plant can possibly present secondary deficiencies, and be more susceptive to hydric deficit, blight and diseases.

Few academic studies describe the distribution of B in the leaves of coconut palm. In plants not fertilized with $\mathrm{B}$, the tendency is to have similar contents in young and in old leaves; in those fertilized, however, the content of B increases, but it does not follow a consistent pattern of distribution between young and old leaves [3]-[16]. The correction of the deficiency in coconut palms is possible after application of B [12]. Doses of $30 \mathrm{~g}$ and $60 \mathrm{~g}$ of boric acid per plant, applied without dilution at the plant's axilla or in the soil, respectively, adequately nourish the plant and do not cause toxicity [3].

Thus, the objectives of this study were to: 1) induce B deficiency in green dwarf coconut palms, and verify the symptoms; 2) describe the distribution of B in leaves of plants with induced B deficiency; 3) describe the distribution of $\mathrm{B}$ in parts of the foliole of coconut palms grown under field conditions, fertilized and non-fertilized with B; and 4) obtain a criterion for the identification of B deficiency.

\section{Material and Methods}

\subsection{Induction of B Deficiency}

Two treatments were used in an experiment conducted in a greenhouse with six replications in a completely randomized design. The treatments consisted in providing a sufficient solution of $\mathrm{B},+\mathrm{B}$, and a $\mathrm{B}$ deficient solution, $-\mathrm{B}$ (starting from 60 days after planting). The site, the acquisition of the seedlings, the management of the treatments, the irrigation, and the experimental conditions are described in [3]-[10].

\subsection{The Presentation of the Symptoms}

The presentation and evolution of the symptoms in the coconut palms in the greenhouse were visually monitored. For each symptom that emerged, affected folioles of the plants $-\mathrm{B}$, as well as the corresponding folioles of the plants $+\mathrm{B}$ (positioned in the same region and leaf) were used as samples to determine the contents of $\mathrm{B}$. The symptoms of deficiency were photographed, as well as the aspect of the corresponding organs in the plants with sufficient B (+B). At the end of the experiment, the leaves were removed from the plants, and as the palm heart 
was exposed the existing leaf primordia were photographed. The leaf primordia were sectioned in apex, center, and base. The symptoms of B deficiency were described by associating them with the foliar boron contents found when each symptom manifested.

\subsection{Distribution of B in Plants Induced and Non-Induced to B Deficiency}

The nutritional status of the plants (data not presented) was monitored during the experiment in a greenhouse (cited above), and also in the field experiment described below (Sampling 4). The samplings intended for the description of B distribution were conducted when the plants were deemed to be in the most advanced stage of B deficiency.

Sampling 1: On April 16, 2007, 406 days after the imposition of boron deficiency, six folioles were collected - three from each side of the central region of each leaf-in order to evaluate the effect of boron deficiency on the mineral composition of the different leaves of the plant (leaf 1 being the youngest).

Sampling 2: On May 10, 2007, 430 days after the imposition of boron deficiency, six folioles were collected from each region - three on each side of the leaf-in order to evaluate the effect of boron deficiency on the mineral composition of the apical, central, and basal region of leaf number four. In the apical region, the collection was performed below the fifth pair of initial folioles; in the central region, at the leaf center, and in the basal region, above the third pair of folioles nearer to the stipe. The central $10 \mathrm{~cm}$ of the folioles were analyzed.

Sampling 3: On May 29, 2007, 444 days after the imposition of boron deficiency, the central folioles of leaf number four were collected (equivalent to leaf number three of the previous collections cited above), and ten folioles were removed - five on each side of the leaf-in order to evaluate the effect of boron deficiency on the mineral composition of the folioles. These leaflets were divided into seven parts, with apex of $14 \mathrm{~cm}$, and the remainder of the folioles was divided into six parts of the same size. The regions were numbered from 1 to 7 , the apical being 1 , and, the basal, 7 . The contents found in the apical part (1) were divided by those found in region $2(1 / 2)$, and so on until reaching the base (1/7), establishing relations.

Sampling 4: To investigate the distribution of B in the seven parts of the foliole under field conditions, plants grown in Campos dos Goytacazes-RJ, Brazil, were sampled on June 18, 2007 in an experiment with a randomized block design, with four treatments, four replications, and two plants per replication. In these plants, the folioles were sectioned in seven positions, resulting in a $4 \times 7$ factorial arrangement. These plants were initially fertilized with boric acid at dosages of $0,5,10$, and $15 \mathrm{~g} \cdot$ plant $^{-1}$, applied to the soil every 4 months, with the first application in February 2003, when the plants were 8 months old. Depending on the development of the coconut palm, starting from May 2005 the doses of boric acid were adjusted to 0, 15, 30, and $45 \mathrm{~g}$ of $\mathrm{B}(\mathrm{OH})_{3}$ plant $^{-1}$, and the interval of application altered to six months. The last application of boron occurred on April 4, 2007, 76 days before the sampling. Ten folioles were sampled from the center of leaf number 9 (youngest leaf $=1$, and so on), five folioles from each side of the leaf. In all the samplings (greenhouse and field), the dry mass of the folioles or of their parts was quantified (data not presented). Between 2003 and 2007, foliar samplings were conducted periodically (data not presented). The soil in the area is Quartzarenicneosoil [17]; the chemical analysis is presented in Table 1.

\subsection{Tissue Conditioning and B Quantification}

The folioles and the leaf primordia were placed in Kraft paper bags. In the laboratory, the folioles were cleaned with cotton wool previously soaked in deionized water, and, subsequently, the midribs were removed. All the material was placed in a forced air circulation chamber at $75^{\circ} \mathrm{C}$ for 48 hours. After the drying, the material was ground in a Wiley mill with a 30-mesh sieve. The material was packed in hermetically sealed tubes. The content of B was determined after submitting $250 \mathrm{mg}$ of plant tissue to dry ashing at $550^{\circ} \mathrm{C}$; nitric acid was added to the ashes at the ratio of 1/60. For the dosage of boron, the method of Azomethine-H was used [17] [18].

\subsection{Data Evaluation}

Since all plants induced to B deficiency developed symptoms, while the same did not occur to the plants with sufficient B, we chose to describe these symptoms. To make a contrast, some pictures of plants with sufficient B were presented. For evaluation of the foliar content, analysis of variance was used, and, when necessary, the test of means. The standard error of the mean was used to represent data homogeneity. The significance levels were 
Table 1. Chemical composition of the soil of the experimental area. Campos dos Goytacazes, Rio de Janeiro, Brazil, 2003.

\begin{tabular}{cccccccccccccccc}
\hline Depth & $\mathrm{pH}$ & $\mathrm{EC}$ & $\mathrm{C}$ & $\mathrm{Al}$ & $(\mathrm{H}+\mathrm{Al})$ & $\mathrm{Ca}$ & $\mathrm{Mg}$ & $\mathrm{Na}$ & $\mathrm{K}$ & $\mathrm{P}$ & $\mathrm{B}$ & $\mathrm{Cu}$ & $\mathrm{Fe}$ & $\mathrm{Mn}$ & $\mathrm{Zn}$ \\
\hline $\mathrm{m}$ & & $\mathrm{mS} / \mathrm{cm}$ & $\mathrm{g} \cdot \mathrm{kg}^{-1}$ & \multicolumn{1}{c}{$\mathrm{mmol}_{\mathrm{c}} \cdot \mathrm{kg}^{-1}$} \\
\hline $0-0.2$ & 6.05 & 244 & 20.4 & 0.5 & 124.6 & 54.8 & 12.0 & 91 & 135 & 8.8 & 0.45 & 1.5 & 11.2 & 27.2 & 1.7 \\
$0.2-0.4$ & 6.09 & 219 & 18.7 & 0.5 & 121.8 & 32.1 & 7.1 & 29 & 104 & 20.0 & 0.35 & 0.9 & 14.8 & 22.5 & 0.8 \\
\hline
\end{tabular}

represented by ${ }^{*}$ for $\mathrm{P}<0.05$ and ${ }^{* *}$ for $\mathrm{P}<0.01$, ${ }^{* * *}$ for $\mathrm{P}<0.001$, and ns (not significant) for $\mathrm{P}>0.05$. The data were analyzed in a factorial scheme, which depended on the number of sampled leaves (9 or 12), or the number of sampling positions on the leaf (3), or the number of sections on the foliole (7).

\section{Results}

\subsection{Description of Symptoms of B Deficiency}

112 days after the induction of B deficiency in the experiment in a greenhouse, some of the folioles of young leaves presented translucent or white spots on the achlorophylled tissue; the epidermis was intact (also observed in a 40× magnifying glass). At the time, B concentration in the folioles of leaf number one (1) of the plants with sufficient $B$ was $13.7 \pm 1.8 \mathrm{mg} \cdot \mathrm{kg}^{-1}$, and in the treatment of $-\mathrm{B}, 8.7 \pm 1.2 \mathrm{mg} \cdot \mathrm{kg}^{-1}$. Due to similar contents between the treatments, the concentration of B was increased in the complete solution from 25 to $50 \mu \mathrm{mol} \cdot \mathrm{L}^{-1}$. On day 142 after the induction of the deficiency, this symptom intensified on the young leaves of the $-\mathrm{B}$ plants, evolving to white stripes parallel to the midrib (Figure 1(A)). With the development of the leaf, some affected areas parched forming cracks at the injury site (Figure 1(B)).

The emergence of young leaves, approximately 170 days after the induction, led the deficient plants $(-\mathrm{B})$ to present corrugations on the dorsal region of the leaf blade with a shape similar to the spots and achlorophylled stripes (Figure 1(C) and Figure 1(D)). On +B plants, the leaf blade was perfect, with no atypical symptom. The $+\mathrm{B}$ plants had boron contents of $27.0 \pm 15.1 \mathrm{mg} \cdot \mathrm{kg}^{-1}$ (leaf 1 ), and in the plants subjected to treatment $-\mathrm{B}$ the contents were $7.2 \pm 1.4 \mathrm{mg} \cdot \mathrm{kg}^{-1}$.

The symptoms of B deficiency always appeared on young leaves. At day 306 after the induction, a cracking similar to a "saw tooth" occurred on the folioles of the leaf base. At this stage, the B contents on the $+B$ plants were $21.1 \pm 7.4 \mathrm{mg} \cdot \mathrm{kg}^{-1}$, and on the boron deficient plants (-B) they were $7.4 \pm 0.77 \mathrm{mg} \cdot \mathrm{kg}^{-1}$ (leaf 3). At day 335 after induction, the folioles had yellowish regions. No descriptions for similar symptoms were found in the literature concerning the cultivation of coconut palm.

In April 2007, 390 days after the induction of B deficiency, the -B plants showed atrophy of the growth point. The youngest leaf had the upper folioles open and exposed, while those from the base were hidden in the center of the canopy (Figure 1(E) and Figure 1(F)). At this stage, the content of B found in B deficient plants was 6.9 $\mathrm{mg} \cdot \mathrm{kg}^{-1} \pm 2.9 \mathrm{mg} \cdot \mathrm{kg}^{-1}$ (leaf 4). Plants with sufficient B (+B) grew new and well-developed leaves (Figure 1(G)); B content was $34.5 \mathrm{mg} \cdot \mathrm{kg}^{-1} \pm 18.3 \mathrm{mg} \cdot \mathrm{kg}^{-1}$ (leaf 4). The B deficient plants were smaller, $1.61 \mathrm{~m}+0.67 \mathrm{~m}$, compared with normal plants, $2.62 \mathrm{~m}+0.55 \mathrm{~m}$ (measured from the base of the root collar to the apex of the highest leaf).

On June 14, 2007, 473 days after induction, it was found that the new leaves had deformations and the folioles had necrotic tips; fusion and malformation occurred to the folioles of the base of the young leaves, the midrib followed the shape of the folioles (Figures $1(\mathrm{H})-(\mathrm{J})$ ). The younger leaves of the plants $-\mathrm{B}$ presented short folioles, had brownish spots along the rachis; on the folioles, in regions without stains, the tissue was slightly yellowish (Figure 1(K)). The base of the root collar was deformed; the surface had necrotic depressions whose colors varied from brownish to black (Figure 1(L) and Figure 1(M)).

The B content in the leaf primordia of the deficient plants (-B) ranged from $9.0 \mathrm{mg} \cdot \mathrm{kg}^{-1}$ to $11.5 \mathrm{mg} \cdot \mathrm{kg}^{-1}$, while in the treatment $+\mathrm{B}$ the content ranged from $17.2 \mathrm{mg} \cdot \mathrm{kg}^{-1}$ to $22.9 \mathrm{mg} \cdot \mathrm{kg}^{-1}$ (Table 2). In the treatment $-\mathrm{B}$, the palm heart presented transversal cracking (Figure $1(\mathrm{~N})$ ). The basal region of the palm heart was necrosed-necrosis was located in the outer region and inside the rachis (Figure $1(\mathrm{O})$ ). In the deficient plants $(-\mathrm{B})$, the palm heart had few, deformed and large leaf primordia, in comparison with those found in the normal plants (+B). In the highest stage of deficiency, the contents of B on the apex, center, and base of the palm heart were, 


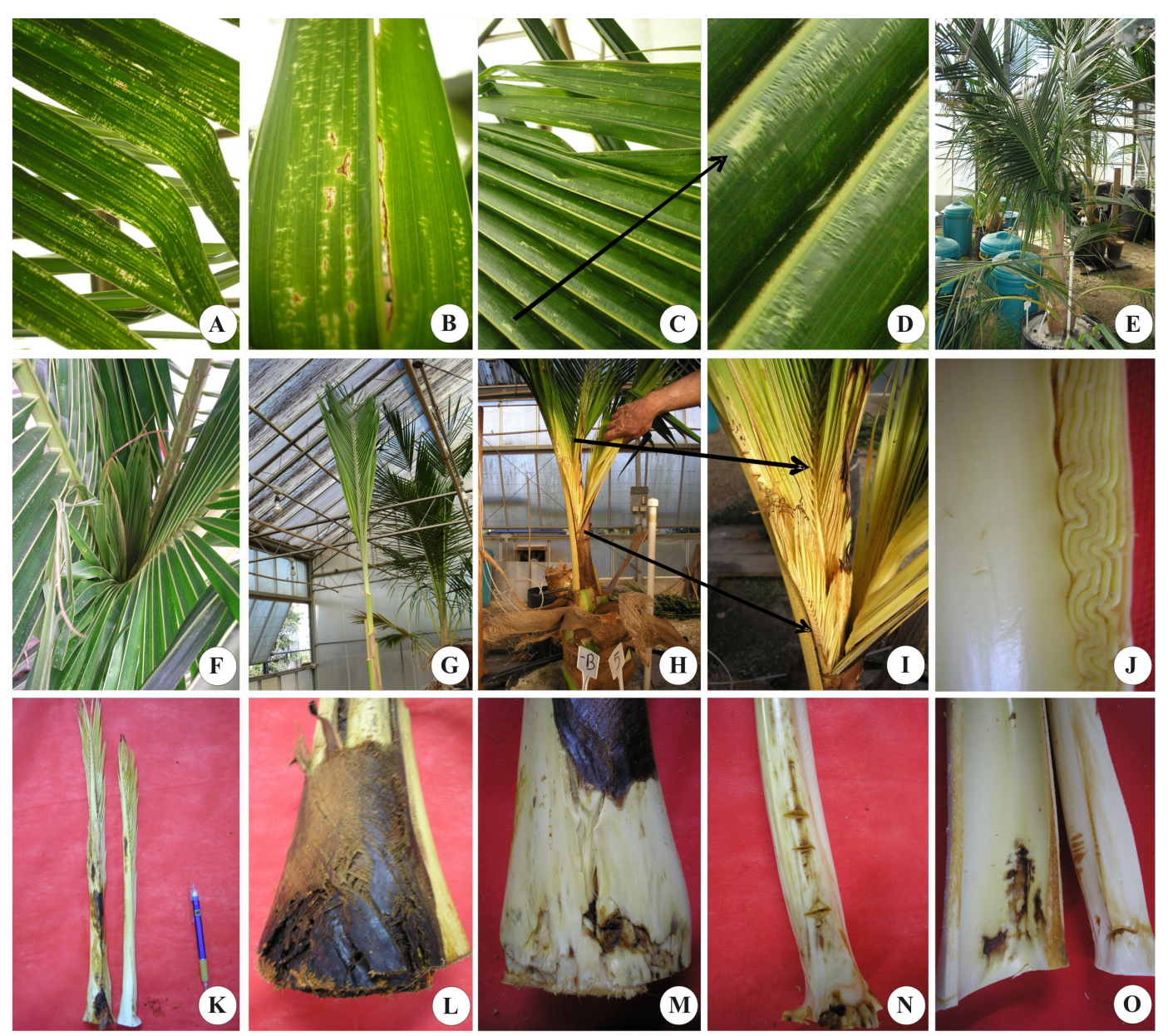

Figure 1. Symptoms of B deficiency in green dwarf coconut palm: (A) Stripes; (B) Exsiccation and tissue rupture; (C) (D) Folioles with necrosis and corrugation; (E) Deficient plant; (F) Growth point; (G) Youngest +B leaf; (H) Youngest -B leaf; (I) -B leaf detail; (J) Folioles deformations; (K) -B leaf primordia; (L) (M) Lesion on root collar; (N) (O) Cracks and external and internal necrosis in the palm heart of the $-\mathrm{B}$ plants.

respectively, $67 \%, 60 \%$, and $39 \%$ of the content of B found in the same regions in the normal plants (+B) (Table 2).

\subsection{Description of B Distribution}

\subsubsection{Description of Distribution of B in Central Folioles of Different Plants}

Boron deficiency reduced the content of this micronutrient in all the coconut palm leaves $(\mathrm{P}<0.001)$, reaching minimum values of $5.0 \mathrm{mg} \cdot \mathrm{kg}^{-1}$ on leaf 1 and $5.1 \mathrm{mg} \cdot \mathrm{kg}^{-1}$ on leaf 2 (Figure 2). In the same leaves of the plants treated with $\mathrm{B}$, the contents were $20.9 \mathrm{mg} \cdot \mathrm{kg}^{-1}$ and $26.7 \mathrm{mg} \cdot \mathrm{kg}^{-1}$, respectively.

In the deficient plants $(-\mathrm{B})$, the contents increased from the youngest to the oldest leaf $(\mathrm{P}<0.001)$. The oldest leaves, 10,11 , and 12 , grew approximately at the time of omission of boron from the nutrient solution. The content of $B$ in the leaves from six to nine varied from $8.9 \mathrm{mg} \cdot \mathrm{kg}^{-1}$ to $10.0 \mathrm{mg} \cdot \mathrm{kg}^{-1}$ (Figure 2), contents above the critical level of $8 \mathrm{mg} \cdot \mathrm{kg}^{-1}$ [13]. In the plants $+B$, the contents of B increased from leaf 1 to 4 , and decreased from 4 to 10, in which they had a new increase $(\mathrm{P}<0.001)$ (Figure 2).

\subsubsection{Description of B Distribution in the Apical, Central, and Basal Regions of Leaf 4}

As expected, the content of $B$ was lower in the plants with deficiency of $B(P<0.001)$ when compared with the plants of the treatment $+\mathrm{B}$ (Table 3). The $\mathrm{B}$ content of the apical, central and basal of deficient plants was $30.5 \%, 52.7 \%$ and $25.0 \%$ of $\mathrm{B}$ concentration in the respective regions of normal plants $(\mathrm{B}+)$. In treatment plants 


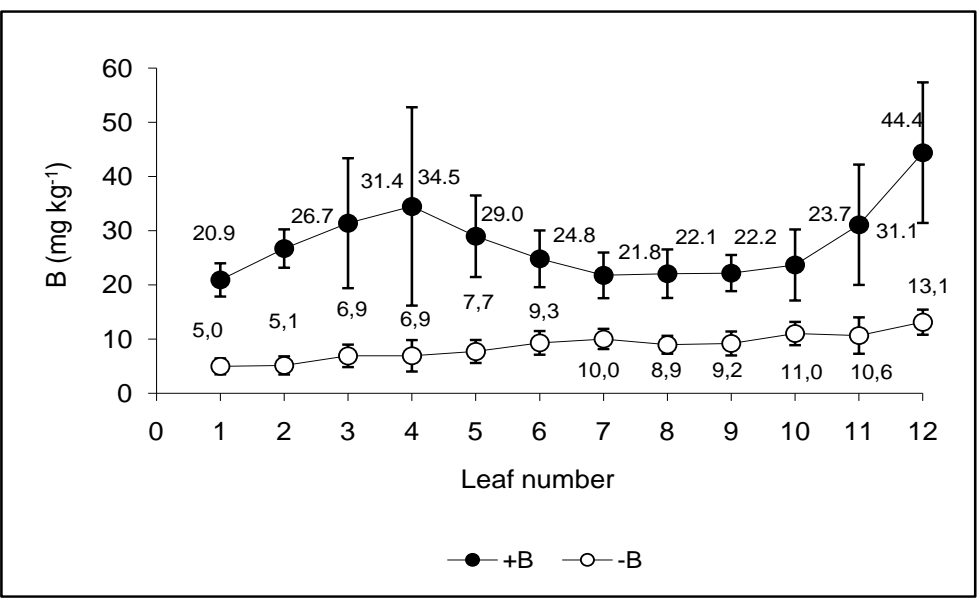

Figure 2. Contents of B in the dry matter of the central folioles of different leaves of green dwarf coconut palm. Plants with sufficient B (+B) and deficiency of B (-B). Leaf 1 is the youngest leaf totally expanded; leaf 2 is the next older one, etc. Vertical lines indicate mean standard error. ns, ${ }^{*}{ }^{* *}$, and ${ }^{* * * *}$ indicate not significant, $\mathrm{P}<0.05, \mathrm{P}<0.01, \mathrm{P}<0.001$, respectively, by $\mathrm{F}$ test and Tukey’s test. Campos dos Goytacazes, Rio de Janeiro, Brazil, 2007.

Table 2. Mean content of B (mg. $\left.\mathrm{kg}^{-1}\right)$ in three regions of the palm heart of green dwarf coconut palms submitted to treatments with sufficient (+B) and deficient B (-B). Campos dos Goytacazes, Rio de Janeiro, Brazil, 2007.

\begin{tabular}{cccc}
\hline Treatment & Apex & Center & Base \\
+B & $17.2 \pm 4.7$ & $19.8 \pm 5.3$ & $22.9 \pm 1.5$ \\
$-B$ & $11.5 \pm 1.9$ & $11.9 \pm 5.0$ & $9.0 \pm 2.0$ \\
\hline
\end{tabular}

Table 3. Contents of B in dry matter of folioles of apical, central, and basal regions of leaf 4 according to treatments with sufficient (+B) and deficient B (-B). Campos dos Goytacazes, Rio de Janeiro, Brazil, 2007.

\begin{tabular}{cccc}
\hline & & Region of leaf & \\
\hline Treatment & Apical & Central & Basal \\
\hline$+B$ & $25.9 \mathrm{Aa}$ & $14.6 \mathrm{Ab}$ & $27.6 \mathrm{Aa}$ \\
$-\mathrm{B}$ & $7.9 \mathrm{Ba}$ & $7.7 \mathrm{Ba}$ & $6.9 \mathrm{Ba}$ \\
\hline
\end{tabular}

+B: B sufficient, $-\mathrm{B}$ : B deficient. The apical region is the tip of the leaf; the central is on the center, and the basal is the nearest to root colar. Means followed by the same capital letter in the column and a lowercase letter in the line do not differ statistically from each other, by $\mathrm{F}$ test at $5 \%$ probability.

$+\mathrm{B}, \mathrm{B}$ concentration was lower in the leaflets of the basal region of the leaf $(\mathrm{P}<0.001)$; in contrast, $\mathrm{B}$ deficient plants showed statistically equal levels in all sampled regions (Table 3), but these data were obtained under conditions of greenhouse (Table 3).

\subsubsection{Description of B Distribution along the Foliole}

In the greenhouse, the content of boron in the apical region (1) of the foliole of plants with sufficient B (+B) was of $293.5 \mathrm{mg} \cdot \mathrm{kg}^{-1}$, decreasing to $23.9 \mathrm{mg} \cdot \mathrm{kg}^{-1}$ in the region just below the apical region (2), with a slight decrease starting from that region, reaching the minimum value of $8.4 \mathrm{mg} \cdot \mathrm{kg}^{-1}$ at the base of the foliole $(7)(\mathrm{P}<$ 0.001) (Figure 3). In the folioles of the $-\mathrm{B}$ plants, the content of boron on the apex of the foliole was of 11.2 $\mathrm{mg} \cdot \mathrm{kg}^{-1}$, gradually decreasing towards the base, with a content of $4.1 \mathrm{mg} \cdot \mathrm{kg}^{-1}(\mathrm{P}<0.001)$ (Figure 3). Thus, even in case of boron deficiency, the content of $B$ tends to be higher at the apex of the folioles.

The content of B was 26 times lower in the apex (1) of the folioles of plants with deficiency of boron (-B), when compared with the $B$ content of the apex of the folioles of the plants with sufficient $B(+B)(P<0.001)$. These relations decrease as they are measured from the apex to the base, reaching the minimum of two at the 


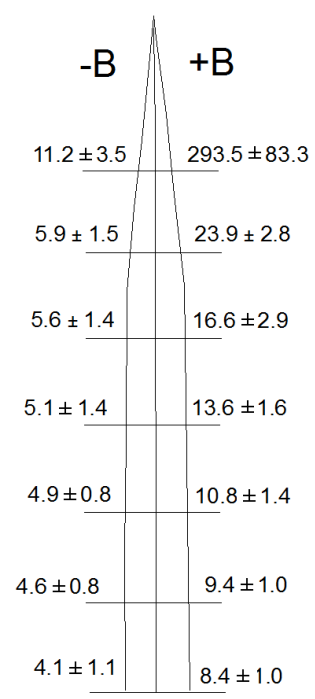

Figure 3. Contents of $\mathrm{B}\left(\mathrm{mg} \cdot \mathrm{kg}^{-1}\right)$ in the seven regions of the central folioles of leaf 4 of green dwarf coconut palms according to the treatments with sufficient B (+B) and deficient B (-B). Data obtained in greenhouse. Campos dos Goytacazes, Rio de Janeiro, Brazil, 2007.

base of the foliole (Figure 3).

In the folioles sampled from plants cultivated in the field and submitted to doses of boron, the content of B decreased from the apex (1) to the base (7) of the folioles independently of the dosage of B used $(P<0.001)$ (Table 4). By comparing the data obtained in field conditions with the data obtained in greenhouse, we observed that the content of B at the apex of folioles, in all doses of B, was lower than the content of B found at the apex of the leaflets of treatment $+B$ (plants cultivated in greenhouse) (Figure 3 and Table 4). The plants that did not receive $B$ by fertilization (dosage 0 ) had content of $B$ of $23.7 \mathrm{mg} \cdot \mathrm{kg}^{-1}$ at the apex of the folioles, decreasing in the subsequent regions $(\mathrm{P}<0.001)$, with a minimum content of $8.7 \mathrm{mg} \cdot \mathrm{kg}^{-1}$ at the base of the leaflet (Table 4). In this case, the response to boron fertilization is higher in the apical region of the foliole. The regions below the apical region have lower levels of B, and thus, underestimation of content of B may occur, even in plants fertilized with B.

The relations among the contents of $\mathrm{B}$ obtained in the apical region and the regions located below this region in deficient plants (-B) (cultivated in greenhouse) varied from 1.9 to 2.7, and at the dosage of 0 (zero) of B in the field experiment they varied from 1.9 to 2.8 (Table 5). In the folioles of the plants with sufficient $B(+B)$ the proportions were high, $12.3(1 / 2)$ to $34.9(1 / 7)$; however, these same proportions when measured for the folioles sampled in the field experiment, for the dosages of 15,30 , and $45 \mathrm{~g}$ of $\mathrm{B}(\mathrm{OH})_{3}$ plant $^{-1}$ were, approximately, two times or more of the proportions found among regions in the treatments of $-\mathrm{B}$ (greenhouse experiment), and at a dosage of 0 (zero) of $\mathrm{B}(\mathrm{OH})_{3}$ plant $^{-1}$ (field experiment) (Table 5). The proportions presented among the different regions of the folioles of the deficient plants $(-\mathrm{B})$ and at the dosage of 0 of $\mathrm{B}(\mathrm{OH})_{3}$ plant $^{-1}$ of the field experiment (Table 5) may be used to assist the diagnosis of B deficiency in coconut palms.

\section{Discussion}

\subsection{Symptoms of B Deficiency}

The symptoms of boron deficiency in coconut tree in an early stage resembled the symptoms described to sorghum (Sorghum bicolor L. Moench), maize (Zea mays L.), peach palm (Bactris gasipaes Kunth) and "açaí" (Euterpe oleracea Mart.). In sorghum [19] and maize [20], in new leaves occur elongated and transparent strips that later turn white and dry and because of the worsening of the deficiency, the growing point necrotizes and dies.

In the peach palm leaf blade of young leaves of boron deficient plants had become wavy [21] [22]. Also in peach palm [23] observed failures in the limbo of the new leaves of boron deficient plants. Boron deficiency in "acai", manifested by small white streaks on young leaves, and, with the intensification of the deficiency, those risks become greater; deficient plants were smaller than the full treatment [24]. 
Table 4. Contents of B, $\mathrm{mg} \cdot \mathrm{kg}^{-1}$, in the seven regions of the central folioles of leaf 9 of green dwarf coconut palms according to different doses of boric acid (g.plant ${ }^{-1}$ ). The sections were 1: apex, 2, 3, 4, 5, 6 regions between the apex and base of the foliole, 7: base.

\begin{tabular}{|c|c|c|c|c|}
\hline \multirow[b]{2}{*}{ Region } & \multicolumn{4}{|c|}{ g B $(\mathrm{OH})_{3}$ plant $^{-1}$} \\
\hline & 0 & 15 & 30 & 45 \\
\hline 1 & $23.7^{*}$ & $68.5^{* *}$ & $73.6^{* * *}$ & $90.2^{* *}$ \\
\hline 2 & $12.8^{*}$ & $21.7^{* *}$ & $25.7^{* *}$ & $28.0^{* *}$ \\
\hline 3 & $11.5 \mathrm{~ns}$ & $16.9^{* * *}$ & $19.8^{* *}$ & $20.8^{* *}$ \\
\hline 4 & $10.8 \mathrm{~ns}$ & $14.1^{* *}$ & $17.5^{* *}$ & $18.6^{* *}$ \\
\hline 5 & $9.8 \mathrm{~ns}$ & $12.6 \mathrm{~ns}$ & $15.1 \mathrm{~ns}$ & $15.8 \mathrm{~ns}$ \\
\hline 6 & $9.2 \mathrm{~ns}$ & $11.3 \mathrm{~ns}$ & $12.6 \mathrm{~ns}$ & $13 \mathrm{~ns}$ \\
\hline 7 & $8.6 \mathrm{~ns}$ & $9.6 \mathrm{~ns}$ & $10.3 \mathrm{~ns}$ & $11.3 \mathrm{~ns}$ \\
\hline
\end{tabular}

ns, ${ }^{* * *},{ }^{* *}$ and ${ }^{* * *}$ represent not significant or significance at $\mathrm{P}<0.05, \mathrm{P}<0.01, \mathrm{P}<0.001$, respectively, for each region of the foliole. Data obtained in field conditions. Campos dos Goytacazes, Rio de Janeiro, Brazil, 2007.

Table 5. Relations obtained from the apical region (region 1) and other regions of the foliole (regions 2, 3, 4, 5, 6, and 7) of the plants induced to B deficiency $(-\mathrm{B})$ and plants with sufficient B $(+\mathrm{B})$ in greenhouse and the same ratios among these regions of green dwarf coconut palms fertilized with doses of boric acid in field conditions. Campos dos Goytacazes, Rio de Janeiro, Brazil, 2007.

\begin{tabular}{|c|c|c|c|c|c|c|}
\hline & $-B$ & $+B$ & 0 & 15 & 30 & 45 \\
\hline Ratio & \multicolumn{2}{|c|}{ Greenhouse } & \multicolumn{4}{|c|}{ g B(OH $)_{3}$ plant $^{-1}$ in field } \\
\hline $1 / 2^{*}$ & 1.9 & 12.3 & 1.9 & 3.2 & 2.9 & 3.2 \\
\hline $1 / 3$ & 2.0 & 17.7 & 2.1 & 4.0 & 3.7 & 4.3 \\
\hline $1 / 4$ & 2.2 & 21.5 & 2.2 & 4.8 & 4.2 & 4.8 \\
\hline $1 / 5$ & 2.3 & 27.3 & 2.4 & 5.4 & 4.9 & 5.7 \\
\hline $1 / 6$ & 2.5 & 31.2 & 2.6 & 6.1 & 5.8 & 6.9 \\
\hline $1 / 7$ & 2.7 & 34.9 & 2.8 & 7.1 & 7.2 & 8.0 \\
\hline
\end{tabular}

*1/2: ratio between the content of B on the apex (1) and the region just below (2), and so on until 1/7, calculated by the division of the content of B of the apex and the base of the foliole (7).

The formation of translucent white or coconut lines was observed in field situations by [25]. One difficulty is the observation that these symptoms appear in young leaves, which makes diagnosis difficult in adult coconut. In field situations, possibly these tissues are affected by pests and diseases, dissimulating the symptom.

The boron content found in plants -B treatment was maximum $9.95 \mathrm{mg} \cdot \mathrm{kg}^{-1}$, while the complete treatment was a minimum of $11.9 \mathrm{mg} \cdot \mathrm{kg}^{-1}$. The data show that the range between deficiency and the appropriate level is small and can be easily corrected by applying supplemental boron. The correction of the deficiency may be carried out through the application of boron in the axilla of the plant [12]. Application of $60 \mathrm{~g}$ of boric acid plant in the soil or in the axilla $30 \mathrm{~g}$ did not lead to toxicity, increased the boron content in the leaves of the coconut palm [3].

\subsection{B Distribution}

\subsubsection{Distribution of B in Central Folioles of Different Plants}

The content of B in the leaves from six to nine varied from 8.9 to $10.0 \mathrm{mg} \cdot \mathrm{kg}^{-1}$, contents above the critical level of $8 \mathrm{mg} \cdot \mathrm{kg}^{-1}$ [13], however, these leaves presented visible symptoms of boron deficiency. In this case, it is possible to infer that the critical level of this micronutrient must be higher than $10 \mathrm{mg} \cdot \mathrm{kg}^{-1}$.

The boron content was higher in old leaves both the deficient plants as well as non-deficient. The mobility of 
B in the phloem depends on the presence of polyols [9] [26]. In case of limited mobility, B would tend to accumulate in older organs, as presented here, since for $+B$ plants there was continuous availability of nutrients. The highest content of $\mathrm{B}$ in the old leaves of the plants grown under deficiency $(-\mathrm{B})$ also suggests that $\mathrm{B}$ is not promptly translocated in the phloem of coconut palms. However, the data presented in this article are not sufficient to infer about the mobility of B in coconut palms, since the young leaves of the deficient plants $(-B)$ had B on its tissue, albeit at low levels (Figure 2).

In B deficient plants, this nutrient is predominantly found in the cell wall, forming complexes with pectic substances [27] [28]. The plants with deficiency of boron $(-B)$ began to present the symptoms of deficiency three months after the omission of B from the nutrient solution. However, the evolution of the symptoms of deficiency was critical after approximately 13 months of the omission of B, which suggests that part of the noncomplexed boron and even the complexed with pectin may have been translocated in the plant [29]. These authors demonstrated that the B bound to the cell wall of sunflowers is not completely immovable, for approximately $28 \%$ of the B initially present in the cell wall was exchanged or released after three hours of omission of $\mathrm{B}$ from the nutrient solution, the rest remained adhered.

\subsubsection{B Distribution in the Apical, Central, and Basal Regions of Leaf 4}

Regarding coconut palms, [30] did not find differences between the contents of B for these regions, apical, central, and basal regions; however, for Paurotis palm the author found lower content in the central region of the leaf. Working with coconut palm trees under field conditions and investigating the influence of the position of the leaflets in the leaf nutrient contents [5], did not find differences between the levels of B obtained in the leaflets of the apical, central and basal leaf 14. In field conditions, the constant airflow helps to drop the temperature around the leaves. On the other hand, in the greenhouse, the temperature was much higher. During the experiment, the average maximum temperature was always above $30^{\circ} \mathrm{C}$ (data not shown).

\subsubsection{B Distribution along the Foliole}

The boron content was higher in the apex of the leaflet, independent treatment, indicating that boron deficient plants shows higher levels of boron as it approaches the apex of the leaflet, since, in field conditions the boron content followed the same distribution. [16] also found higher levels of boron at the apex of folioles of coconut palms and Paurotis palm. The African oil palm also has higher content of B at the apex of folioles [31]. A more intense transpiration in these plants occurs, possibly, at the apex of the folioles, since the movement of B inside plants is, often, related to the transpiration stream, which would lead to greater accumulation of boron in organs or in part of them, of increased transpiration.

In conclusion, the visual symptoms of boron deficiency in coconut palms after the omission of boron from the solution take time to emerge (approximately 3 months) and occur on young leaves. Early detection is difficult, especially in young and mature plants due to size, and leaf sampling is necessary. The deficiency leads to deformation on leaves, folioles, palm heart, and roots, which present content levels with a small margin between sufficiency and deficiency of B. With the data presented here, it is proposed that, for diagnosis of B deficiency, the youngest leaf of the plant should be sampled [16] [32], since it represents the latest development, regardless of the presence of the symptoms of B deficiency, with the collection of the apex and the center (or base) of the foliole, thus obtaining the relation between the contents at these two positions. Considering the results of this work, and also based on [16], the collection of folioles from the leaf regions (apical, central, and basal) does not interfere on the results.

\section{Conclusions}

1) The symptoms of boron deficiency in coconut palms are: folioles with spots varying from white to translucent; tissue necrosis in the region of the spots; corrugation with a shape similar to the white spots and lines; young leaves are hidden among others already grown; absence of spear; necrosis on the apex of the folioles, corrugation on blade and midrib. Palm heart acquires brownish stains, with necrosis on both sides of each rachis.

2) After the analysis of B, it is necessary to relate the content of B of the apex of the foliole and the content of the center or the base. If the relation obtained is close to the one presented in this work, 2.2 or 2.7, respectively (Table 5), the possibility of response to the application of B is high, even if the plant is not presenting visual symptoms of B deficiency. 


\section{Acknowledgements}

The authors would like to thank Instituto Federal de Educação, Ciência e Tecnologia do Espírito Santo—IFES for the financial support for the translation of this article.

\section{References}

[1] Ramos, M.J.M., Monnerat, P.H., Carvalho, A.J.C.de, Pinto, J.L.deA. and Silva, J.A.da (2009) Visual Symptons of Macronutrients and Boron Deficiency in "Imperial” Pineapple. Revista Brasileira de Fruticultura, 31, 252-256. http://dx.doi.org/10.1590/S0100-29452009000100035

[2] Freitas, M.S.M., Monnerat, P.H., Carvalho, A.J.C.de and Vasconcellos, M.A.daS. (2011) Deficiency Symptoms of Macronutrientes and Boron in Sweet Passion Fruit Plant. Revista Brasileira de Fruticultura, 33, 1329-1341. http://dx.doi.org/10.1590/S0100-29452011000400034

[3] Pinho, L.G.R., Monnerat, P.H., Pires, A.A. and Santos, A.L.A. (2008) Boron Absorption and Redistribution in Green Dwarf Coconut Tree. Pesquisa Agropecuária Brasileira, 43, 1769-1775. http://dx.doi.org/10.1590/S0100-204X2008001200018

[4] Kamalakshiamma, P.G. and Shanavas, M. (2002) Boron Deficiency in Coconut. Symptoms and Corrections. Indian Coconut Journal, 32, 1-5.

[5] Santos, A.L. (2002) Establishment of Rules for Foliar Sampling for Assessment of Nutritional Status and Mineral Fertilization of Green Dwarf Coconut in North Fluminense. Thesis, Universidade Estadual do Norte Fluminense Darcy Ribeiro, Rio de Janeiro.

[6] Elliott, M.L., Broschat, T.K., Uchida, J.Y. and Simone, G.W. (2004) Compendium of Ornamental Palm Diseases and Disorders. Amer. Phytopath. Soc. Press, St. Paul.

[7] Broschat, T.K. (2007) Boron Deficiency Symptoms in Palms. Palms, 51, 115-126.

[8] Power, P.P. and Woods, W.G. (1997) The Chemistry of Boron and Its Speciation in Plants. Plant and Soil, $193,1-13$. http://dx.doi.org/10.1023/A:1004231922434

[9] Hu, H., Penn, S.G., Lebrilla, C.B. and Brown, P.H. (1997) Isolation and Characterization of Soluble Boron Complexes in Higher Plants.The Mechanism of Phloem Mobility of Boron. Plant Physiology, 113, 649-655. http://dx.doi.org/10.1104/pp.113.2.649

[10] Pinho, L.G.R., Campostrini, E., Monnerat, P.H., PiresNetto, A.T., Marciano, C.R. and Soares, Y.J.B. (2010) Boron Deficiency Affects Gas Exchange and Photochemical Efficiency (JPI Test Parameters) in Green Dwarf Coconut. Journal of Plant Nutrition, 33, 439-451. http://dx.doi.org/10.1080/01904160903470471

[11] Ramos, V.H.V., Pinto, A.C.Q., Aragão, W.M., Gomes, A.C., Junqueira, N.T.V., Lobato, E. and Oliveira, M.A.S. (2004) Behavior of Dwarf Cultivars and Hybrids of Coconut in Brasília, Distrito Federal. Revista Brasileira de Fruticultura, 26, 363-365. http://dx.doi.org/10.1590/S0100-29452004000200045

[12] dos Santos, A.L., Monnerat, P.H. and Alves, E.A.B. (2003) Foliar Boron Content Depending on the Application of Borax in Leaf Axil of Green Dwarf Coconut in Norte Fluminense. Pesquisa Agropecuária e Desenvolvimento Sustentável, 1, 165-171.

[13] Chew, P.S. (1978) Nutrition of Coconuts-A Review for Formulating Guidelines on Fertilizer Recommendations in Malaysia. Planter, 54, 115-141.

[14] Ferreira, J.M.S. (1998) Pests of Coconut. In: Ferreira, M.J.S., Warwick, D.R.N. and Siqueira, L.A., Eds., The Coconut in Brazil, 2nd Edition, Embrapa-CPATC, Aracaju, 189-267.

[15] Broschat, T.K. (2007) Boron Deficiency, Phenoxy Herbicides, Stem Bending, and Branching in Palms. Is There a Connection? Palms, 51, 161-163.

[16] Broschat, T.K. (2011) Uptake and Distribution of Boron in Coconut and Paurotis Palms. HortScience, 46, $1683-1686$.

[17] Jones Jr., J.B., Wolf, B. and Mills, H.A. (1991) Plant Analysis Handbook: A Practical Sampling, Preparation, Analysis, and Interpretation Guide. Micro-Macro Publishing, Athens.

[18] Malavolta, E., Vitti, G.C. and Oliveira, S.A. (1997) Evaluation of the Nutritional State of Plants. Associação Brasileira para Pesquisa da Potassa e do Fosfato, Piracicaba.

[19] Alves, V.M.C., Pitta, E.G.V., Coelho, A.M., France, G.E. and de Oliveira, C.A. (2003) Diagnose Foliar. Technical Communication No. 90. http://www.cnpms.embrapa.br/publicacoes/publica/2003/comunicado/Com_90.pdf

[20] Coelho, A.M., France, G.E., Pitta, E.G.V. and Alves, V.M.C. (2002) Growing Corn: Foliar Diagnosis of Plant Nutritional Status. Technical Communication No. 45. http://www.cnpms.embrapa.br/publicacoes/publica/2002/comunicado/Com_45.pdf 
[21] da Silva, J.R.A. and de Souza Falcão, N.P. (2002) Characterization of Symptoms of Nutritional Deficiencies in Peach Palm Seedlings Grown in Nutrient Solution. Acta Amazonica, 32, 529-539.

[22] de Matos, G.S.B., Fernandes, A.R. and Carvalho, J.G. (2013) Symptoms of Deficiency and Growth of Peach Palm Seedlings Due to Omission of Micronutrients. Revista de Ciências Agrarias, 56, 166-172. http://dx.doi.org/10.4322/rca.2013.025

[23] La Torraca, S.M., Haag, H.P. and Dechen, A.R. (1984) Mineral Nutrition of Tropical Fruit I. Symptoms of Nutritional Deficiencies in Peach Palm. O Solo, 76, 53-56.

[24] Naiff, A.P.M., Viégas, I.deJ.M. and de Lima, S.S. (2003) Characterization of Symptoms of Micronutrient Deficiencies in Plants of Açaí (Euterpe oleracea Mart.). In: I Seminar on Scientific Initiation UFRA and VII Seminar on Scientific Initiation, Embrapa Amazônia Oriental, Belém.

[25] MirisolaFilho, L.A. (2002) Growing Dwarf Coconut. Aprenda Fácil., Viçosa.

[26] Brown, P.H. and Hu, H. (1996) Phloem Mobility of Boron Is Species Dependent: Evidence for Phloem Mobility in Sorbitol Rich Species. Annals of Botany, 77, 497-506. http://dx.doi.org/10.1006/anbo.1996.0060

[27] Hu, H. and Brown, P.H. (1994) Localization of Boron in the Cell Walls of Squash and Tobacco and Its Association with Pectin. Plant Physiology, 105, 681-689.

[28] Cakmak, I. and Römheld, V. (1997) Boron Deficiency-Induced Impairments of Cellular Functions in Plants. Plant and Soil, 193, 71-83. http://dx.doi.org/10.1023/A:1004259808322

[29] Dannel, F., Pfeffer, H. and Römheld, V. (2000) Characterization of Root Boron Pools, Boron Uptake and Boron Translocation in Sunflower Using the Stable Isotopes 10B and 11B. Australian Journal of Plant Physiology, 27, 397405.

[30] EMBRAPA-Embrapa Solos (2009) Manual of Chemical Analysis of Soils, Plants and Fertilizers. Embrapa Information Technology, Brasília, 627p.

[31] Rajaratnam, J.A. (1972) The Distribution and Mobility of Boron within the Oil Palm, Elaeisguineensis L. I. Natural Distribution. Annals of Botany, 36, 289-297.

[32] Mills, H.A. and Jones Jr., J.B. (1996) Plant Analysis Handbook II. A Practical Sampling, Preparation, Analysis, and Interpretation Guide. Micro-Macro Publishing, Athens. 
Scientific Research Publishing (SCIRP) is one of the largest Open Access journal publishers. It is currently publishing more than 200 open access, online, peer-reviewed journals covering a wide range of academic disciplines. SCIRP serves the worldwide academic communities and contributes to the progress and application of science with its publication.

Other selected journals from SCIRP are listed as below. Submit your manuscript to us via either submit@scirp.org or Online Submission Portal.
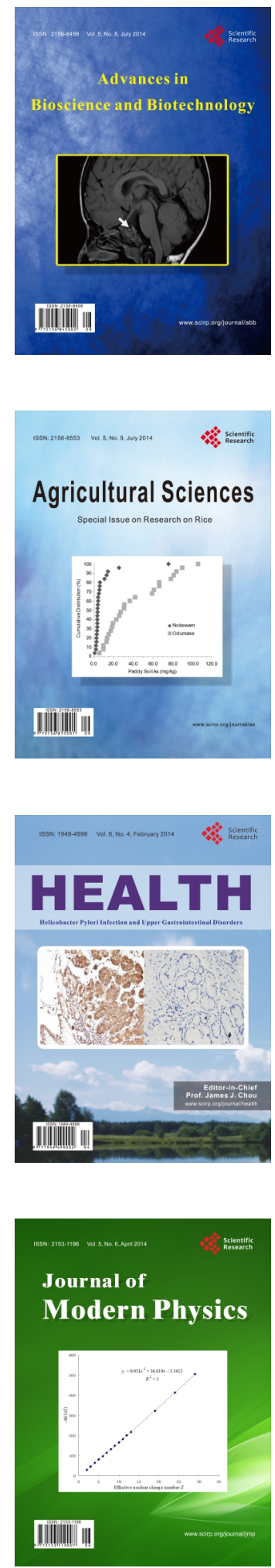
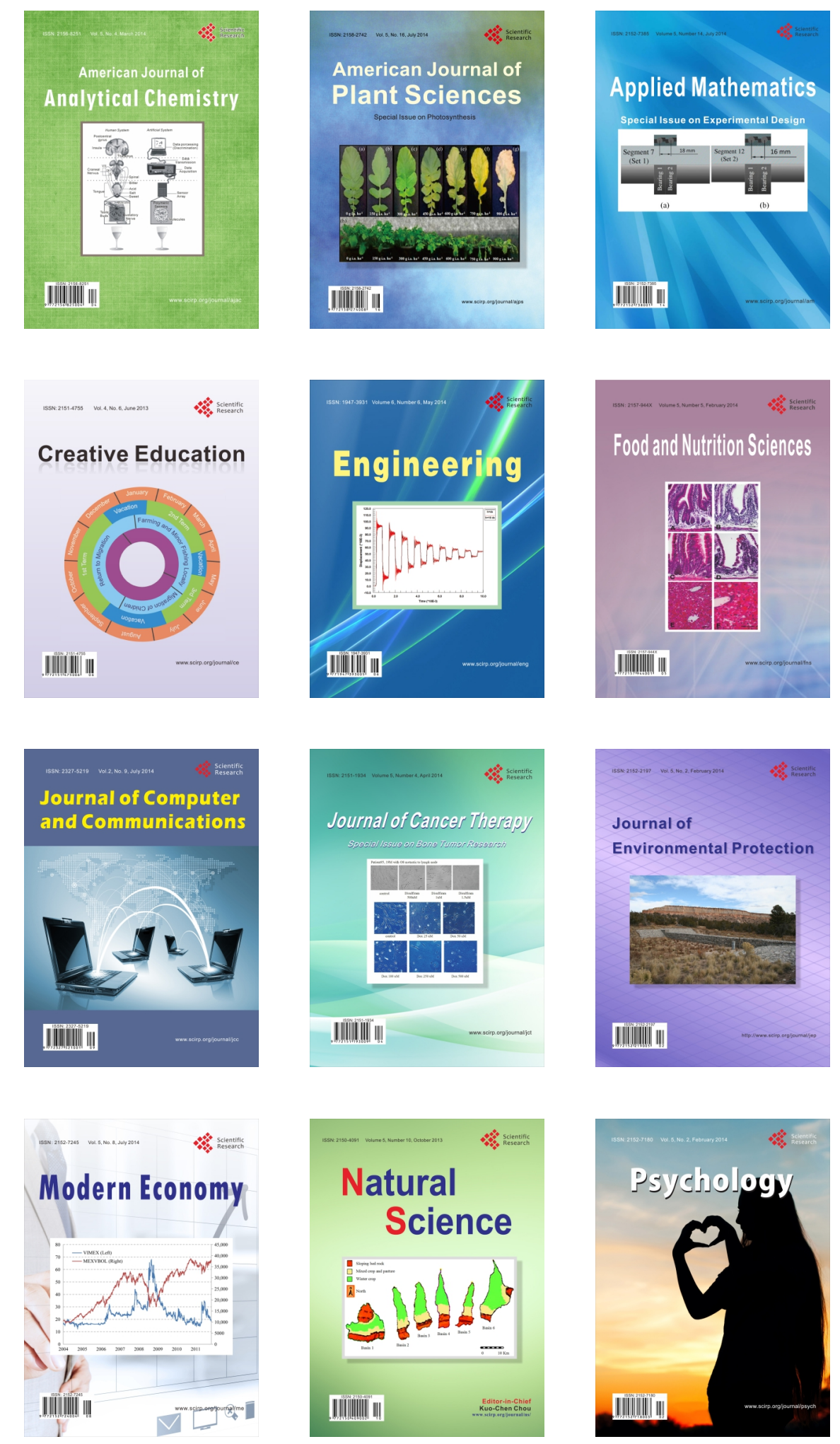